\title{
Interleukin-1, immune activation pathways, and different mechanisms in osteoarthritis and rheumatoid arthritis
}

\author{
Bruce Kirkham
}

The properties of interleukin-1 suggest that it has a central role in the immunopathology of many arthritides (figure). It is now more than 10 years since it was realised that numerous biological activities were due to a single agent called interleukin-1 (IL-1) ${ }^{1}$ (now known to be two related proteins, IL- $1 \alpha$ and IL- $1 \beta^{2}$ ). The functions of IL-1, such as $\mathrm{T}$ cell activation, ${ }^{3}$ stimulation of cellular production of prostaglandin $\mathrm{E}_{2}$ and $\mathrm{I}_{2},{ }^{4}$ interleukin-1, ${ }^{5}$ and interleukin- $6,{ }^{6}$ help for B cell growth, ${ }^{7}$ induction of endothelial cell adhesion molecule expression, ${ }^{8}$ stimulation of chondrocyte stromelysin, ${ }^{9}$ synovial cell collagenase, and plasminogen activator production, ${ }^{10-12}$ induction of bone resorption, ${ }^{13}$ and hepatic acute phase protein synthesis, show its enormous potential for mediating pathological processes. The 10th birthday of this 'first interleukin' was recently celebrated in a comprehensive review of our current knowledge by di Giovine and Duff. ${ }^{14}$ In addition to extending the role of IL-1 as an activator of immune function, recent data have provided a more complete picture of a physiological system, with negative feedback pathways and inhibitors of IL-1 activity. This review of IL-1 covers recent in vitro findings together with data from in vivo studies and discusses the implications for rheumatoid arthritis and osteoarthritis.

Interleukin-1: a complex biological system CONTROL OF PRODUCTION

Interleukin- $1 \alpha$ and IL- $1 \beta$ protein production is controlled at several levels, including gene transcription, messenger RNA (mRNA) stability, translation to form the $31 \mathrm{kd}$ precursor protein, and release of the processed mature $17.5 \mathrm{kd}$ protein. ${ }^{15}$ The complexity of IL-1 production is illustrated by the high concentrations of IL-1 mRNA that can be stimulated by adherence of monocytes to glass. ${ }^{16}$ This mRNA is not translated into protein, however, unless a second signal (usually endotoxin) is supplied. Human monocytes are very sensitive to endotoxin and can produce IL-1 in response to the low concentrations commonly found in tissue culture media. ${ }^{16}$ Both endotoxin and IL-1 stimulate transcription and translation of IL-1..$^{5}$ Glucocorticoids can reduce IL-1 transcription and translation, ${ }^{17} 18$ in contrast with prostaglandins, which reduce translation without changing gene transcription. ${ }^{19}$

Unlike most secreted proteins, IL-1 lacks a distinct cleavage site for the $\mathrm{N}$-terminus, resulting in much IL-1 remaining cell associated. ${ }^{20}$ Interleukin- $1 \beta$ is secreted more efficiently than IL- $1 \alpha$ and makes up most extracellular IL-1 (in cell supernatants and body fluids). ${ }^{21}$ Interleukin- $1 \alpha$ is found associated with cells and may form a 'membrane bound' biologically active IL-1. ${ }^{22}$ This finding is still in contention, however. ${ }^{23}$ Despite having only $26 \%$ homology, IL- $1 \alpha$ and IL- $1 \beta$ bind to the same receptors and seem to have similar activity. ${ }^{15} 24$ Interleukin$1 \beta$ is vulnerable to oxidation, in contrast with IL- $1 \alpha$, which is a stable molecule. ${ }^{25}$

\section{INTERLEUKIN-1 INHIBITORS}

Inhibitors of the biological activities of IL-1 were noted when it was first detected in body fluids, including synovial fluid. ${ }^{26-28}$ The recent characterisation of the $22 \mathrm{kd}$ inhibitor is a major advance in IL-1 biology. ${ }^{29} 30$ This inhibitor is related to the interleukin-1 family with $26 \%$ sequence homology to IL-1 $\beta$ and $19 \%$ homology to IL- $1 \alpha$ and competes for the IL- 1 receptor. The natural inhibitor has shown functional inhibition of IL-1 induced neutrophil adherence to endothelial cells and cartilage degradation, ${ }^{31}$ and the recombinant protein inhibits IL-1 stimulated prostaglandin synthesis in vitro. ${ }^{30} \mathrm{It}$ is produced by monocyte lineage cells with different kinetics and in response to differing stimuli than IL-1. Apparently, immature monocytes predominantly secrete IL-1, in contrast with mature macrophage-like cells, which produce the inhibitor. ${ }^{32}$ It is unclear if the same cell can produce both.

Natural inhibitors of cytokines make measurement of in vivo cytokine concentrations difficult, and this difficulty is increased by the presence of binding factors in plasma, including $\alpha_{2}$ macroglobulin. ${ }^{33}$ Additionally, specific cytokine binding immunoglobulin autoantibodies have been shown for IL-1 $\alpha$ and tumour necrosis factor $\alpha .^{34}$ These antibodies may function as physiological carriers for cytokines as their binding affinity for IL-1 is less than the high affinity receptor found on $T$ lymphocytes but greater than the affinity of receptors found on cells such as endothelial cells. Recent findings suggest that these two forms of the IL-1 receptor with low and high affinities for IL-1 are expressed on different cell types. ${ }^{35}$ High affinity IL-1 receptors have been identified on synovial cells from normal subjects and those with osteoarthritis and rheumatoid arthritis. ${ }^{36}$
The Walter and Eliza Research, Post Office, Royal Melbourne Hospital, Victoria 3050 , Australia

B Kirkham 
LOINTS

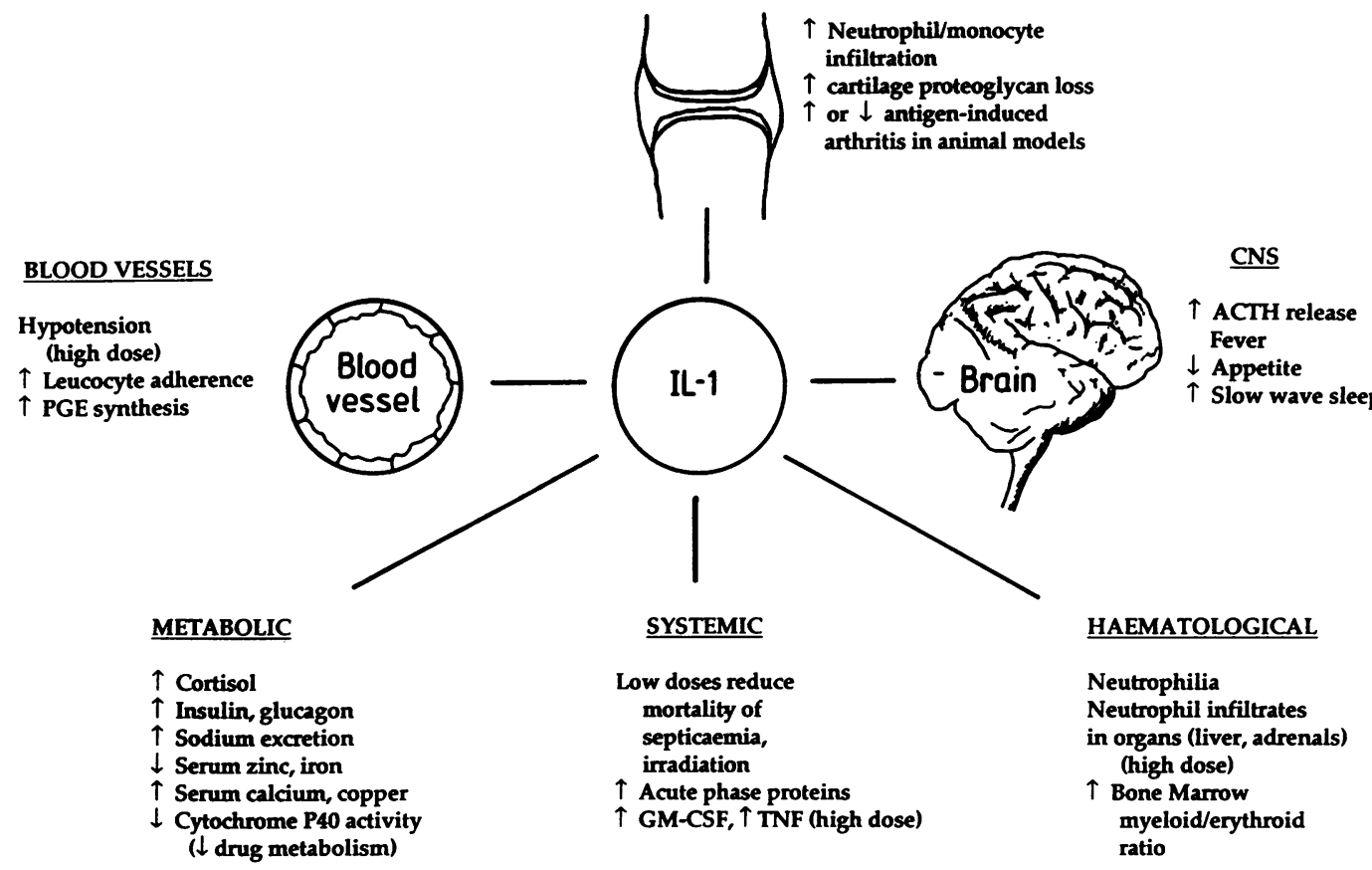

Biological activities of interleukin-1 (IL-1) (established by in vivo studies). PGE = prostaglandin $E ; C N S=$ central nervous system; $A C T H=$ adrenocorticotrophic hormone; $G M-C S F=$ granulocyte-monocyte colony stimulating factor; TNF $=$ tumour necrosis factor.

THE CYTOKINE NETWORK

Interleukin- 1 is part of a network of cytokines which can interact in additive, synergistic, or inhibitory ways through direct cytokine effects or the effects of cytokines on cellular receptors. ${ }^{37-39}$ Recent examples of the complexity of in vitro interactions are the additive or inhibitory effects of IL-1 and platelet derived growth factor on fibroblast proliferation depending on the presence of indomethacin, ${ }^{40}$ and the change in endotoxin stimulated U937 cell IL-1 production induced by interferon $\gamma .^{41}$ Pretreatment of this cell line with interferon $\gamma$ results in prolonged IL- $1 \alpha$ and IL- $1 \beta$ gene expression for 16 hours, in contrast with the normal transient response. Many cytokines, including IL-1 $\alpha$ and IL-1 $\beta$, tumour necrosis factor $\alpha$, IL-6, epidermal growth factor, transforming growth factory $\beta$, and granulocyte-macrophage colony stimulating factor, have been detected in rheumatoid synovial fluids, indicating a large number of potential in vivo interactions. ${ }^{314243}$ For example, transforming growth factor $\beta$ can antagonise many IL-1 mediated activities in vitro and is present at high concentrations in rheumatoid synovial fluids. ${ }^{31}$ Cytokines also have important interactions with prostaglandins and leukotrienes, which were recently reviewed in detail in this journal. ${ }^{44}$ Interleukin-1 is a potent stimulus for prostaglandin $\mathrm{E}_{2}$ production. Prostaglandin $\mathrm{E}_{2}$, however, reduces IL-1 production, demonstrating another potential natural feedback loop. In contrast, leukotrienes stimulate IL-1 production. Changes in leukotriene $\mathrm{B}_{4}$ production are thought to explain the reduction of in vitro IL-1 production that accompanies a high polyunsaturated omega-3 fatty acid (fish oil) diet. ${ }^{45}$ The in vivo importance of interrupting prostaglandin negative feedback on IL-1 production by non-steroidal antiinflammatory drug treatment has not yet been resolved.

\section{Interleukin-1 in vivo}

IN VIVO DISTRIBUTION

Cytokines (and their inhibitors) have been detected in synovial fluids by bioassay and immunoassay and more recently in synovial tissue by mRNA analysis (northern blot, slot blot, or in situ hybridisation) or immunohistological techniques. $31424346-48$ Interleukin-1 $\alpha$ and IL-1 $\beta$ have been detected in the peripheral blood of patients with rheumatoid arthritis but not osteoarthritis. ${ }^{49}$ Concentrations of IL-1 $\beta$ correlated with the Ritchie index and erythrocyte sedimentation rate in cross-sectional analysis, and synovial fluid concentrations of IL- $1 \beta$ correlated with clinical signs in paired knee joint samples from patients with rheumatoid arthritis. ${ }^{49}$ The source of circulating IL-1 $\beta$ is unclear as although concentrations are increased in synovial fluids, recent studies have shown that peripheral blood cells from subjects with rheumatoid arthritis spontaneously secrete IL-1. ${ }^{50} 51$ These findings are difficult to interpret as most experiments were performed in conditions that did not exclude laboratory stimulation by adherence of monocytes or low concentrations of endotoxin. Both of these reports, however, did compare the rheumatoid samples with control samples from normal or osteoarthritic patients which did not spontaneously produce IL-1, though they had undergone similar laboratory procedures. The above reservations are even more relevant to many experiments using cultured synovial membrane cells where access to normal control tissue can be difficult. 
By in situ hybridisation analysis of rheumatoid synovial membrane, Duff and colleagues showed tht CD14 positive macrophages contain IL-1 $\beta$ mRNA. ${ }^{49}$ We detected IL-1 $\beta$, by immunohistological techniques, in cells scattered throughout perivascular aggregates and in some lining layer cells in rheumatoid synovial membrane. ${ }^{52}$ These techniques will be increasingly applied to assess cytokine production in disease states and models of inflammation and to assess modes of drug action in vivo. For example, we showed a significant decrease in IL- $1 \beta$ staining after 12 weeks of sodium aurothiomalate treatment in sequential synovial biopsy specimens from six patients with rheumatoid arthritis. This decrease occurred without significant changes in the synovial mononuclear cell composition. ${ }^{53}$ These methods will provide a picture of the cytokine network present in different disease states, and for IL-1 at least, an assessment of the balance between cytokine and inhibitor production may soon be possible.

\section{IN VIVO FUNCTION}

Most of the activities ascribed to IL-1 have been determined in vitro and must be regarded as potential functions. The in vivo function of cytokines can be assessed by the use of recombinant cytokines and cytokine inhibitors, by the use of specific anticytokine monoclonal antibodies, or by the use of transgenic animal models. Henderson and Pettipher showed that intra-articular administration of IL-1 $\alpha$ or IL- $1 \beta$ in rabbits causes rapid loss of cartilage proteoglycan and a rapid increase of neutrophils and monocytes in the synovial compartment. ${ }^{54}$ Interestingly, synovial fluid prostaglandin concentrations did not rise and no clinical signs of inflammation such as swelling or warmth were seen. Tumour necrosis factor $\alpha$ had less potent but similar effects and, together, IL- $\beta$ and tumour necrosis factor $\alpha$ showed synergistic effects, confirming in vitro predictions. ${ }^{55}$ Repeated intra-articular injections of IL-1 into the ankles of normal rats produces a synovial cellular infiltrate and fibrosis in the absence of cartilage or bone destruction. ${ }^{56}$ Interleukin-1 given intra-articularly or systemically can exacerbate low grade antigen induced arthritis in animal models. ${ }^{5657}$ The in vivo picture is complicated, however, as the exacerbation seen in collagen induced arthritis varied depending on the relative timing of disease stimulus and cytokine. ${ }^{58}$ Jacobs et al reported that intraarticular IL-1 $\beta$ actually decreased antigen induced arthritis when given both before or during the arthritis. ${ }^{59}$ The timing and dose of cytokine in relation to a stimulus is crucial. Although high dose IL-1 given intravenously causes toxic effects, such as hypotension, fever, and neutrophilia, ${ }^{60}$ low dose IL-1 given before noxious stimuli, such as endotoxin, falciparum malaria, or radiation, can improve survival in animal models. ${ }^{61}$ The mechanisms for these effects are not known but may involve induction of cytokine inhibitors, reduction of cytokine receptor expression, or stimulation of cortisol production, and may demonstrate some of the physiological roles of IL-1. Many of these protective effects can be abrogated by pretreatment with non-steroidal anti-inflammatory drugs.

These models suggest that IL-1 activity in vivo might contribute to cartilage damage and promote inflammatory changes. This activity, however, will be suppressed by natural inhibitors. Inhibition of interleukin-1 activity increases over time in antigen induced arthritis in rabbits. ${ }^{62}$ Two studies of patients with rheumatoid arthritis attempted to correlate synovial fluid IL-1 concentrations with measures of local joint damage. Saxne and colleagues showed that synovial fluid concentrations of IL-1 do not correlate with synovial fluid proteoglycan fragment concentrations. ${ }^{63}$ Miyasaka and colleagues, however, reported that concentrations of IL-1 secreted by cell cultures from synovial biopsy specimens did correlate with radiographic damage. ${ }^{64} \mathrm{~A}$ single study reported modest short term improvements in patients with rheumatoid arthritis treated with an IL-1 inhibitor. ${ }^{65}$

\section{Interleukin-1 in osteoarthritis}

INTERLEUKIN-1 PROPERTIES AND OSTEOARTHRITIS As outlined above, much attention has been paid to the role of IL-1 in inflammatory arthropathies such as rheumatoid arthritis. Interleukin-1 has also been consistently detected in synovial fluid samples from patients with osteoarthritis. ${ }^{264266}$ The processes initiating osteoarthritis are unknown and it is unclear if the end stage of cartilage failure is due mainly to proteoglycan, collagen, subchondral bone, or vascular defects. ${ }^{6768}$ It is known that raised levels of degradative enzymes, such as collagenase and stromelysin, are present in osteoarthritic cartilage as is plasminogen activator, an important activator of these enzymes. ${ }^{69} 70$ Interleukin-1 has many properties, such as stimulation of stromelysin, collagenase and plasminogen activator secretion, and direct bone resorbing activities, that might account for many of these changes. Tumour necrosis factor $\alpha$ produces similar changes and has also been found in some osteoarthritic synovial fluids. ${ }^{71}$ It is generally found in a lower proportion of osteoarthritic synovial fluids than is IL-1. This suggests that synergistic effects at very low concentrations may occur in some patients, contributing to the variable rates of disease progression seen between patients. In addition to its catabolic effects, IL-1 has anabolic effects, such as increasing fibroblast collagen synthesis, ${ }^{72}$ which might account for other changes, such as osteophyte formation.

IN VIVO DISTRIBUTION IN OSTEOARTHRITIS

It is now clear that infiltrates of mononuclear cells are commonly found in osteoarthritic synovial membranes, even in patients with early disease. ${ }^{7374} \mathrm{We}$ and other groups investigated the distribution of IL-1 $\beta$ in the osteoarthritic synovium, using immunohistological techniques. Pelletier et al reported IL-1 $\beta$ in osteoarthritic synovial lining layer cells, with some 
staining in the deeper tissues. ${ }^{75}$ Shinmei et al demonstrated IL-1 $\beta$ staining in osteoarthritic chondrocytes. ${ }^{76}$ We detected IL-1 $\beta$ staining consistently in synovial lining layer cells, with almost no IL-1 $\beta$ being detected in the perivascular lymphoid aggregates that were commonly present. ${ }^{52}$ This distribution of IL-1 $\beta$ staining was different from that found in rheumatoid arthritis, where it was mainly in the perivascular aggregates. This suggests that although IL-1 is present in both the rheumatoid and osteoarthritic synovial compartment, it is stimulated by different processes. The presence of IL-1 staining in the perivascular cellular infiltrates in rheumatoid arthritis suggests that these infiltrates may be the site of an active cell mediated immune process which interacts with other components of the systemic immune system. This is supported by the systemic nature of rheumatoid arthritis, with circulating IL- $1^{49}$ and IL-1 producing cells, ${ }^{50} 51$ raised erythrocyte sedimentation rate, and soluble interleukin- 2 receptor concentrations. ${ }^{77}$ In contrast, the localised lining cell activation in osteoarthritis would produce localised increases of IL-1 in the synovial fluid in the absence of systemic immune activation. Many cells in the osteoarthritic synovial membrane infiltrate may be inactive bystander cells, as suggested for the rheumatoid synovial membrane by Ziff in $1974 .^{78}$ The suggestion of differing mechanisms of IL-1 production in these diseases is supported by the results of Brennan and colleagues. ${ }^{79}$ They found that in vitro osteoarthritic synovial cells produced low concentrations of IL-1 compared with the high concentrations produced by rheumatoid synovial cells. Both groups produced high concentrations of tumour necrosis factor $\alpha$. When monoclonal antibodies to tumour necrosis factor $\alpha$ were added to the system, however, IL-1 production was reduced only in the group with rheumatoid arthritis, with no change occurring in IL-1 production by osteoarthritic synovial cells.

\section{A POTENTIAL ROLE IN OSTEOARTHRITIS}

The detection of IL-1 in osteoarthritic synovial membranes has been in patients with established disease, highlighting the difficulties of studying early disease in humans. It is therefore unclear if the lining cell layer production of IL-1 is an early or late development. Goto and colleagues reported that monocytes can be stimulated to produce IL-1 by fragments of human cartilage, in particular by collagen type II. ${ }^{80}$ For osteoarthritis a possible mechanism relating cytokines to disease might be an initial insult to cartilage with release of cartilage fragments which then stimulate synovial lining cell production of IL-1. The properties of IL-1 may then contribute to the progress of the lesion. In this situation the balance of cytokine and inhibitor would play a crucial part.

The importance of IL-1 (and other cytokine) secretion in the early stages of disease will be best studied in animal models. ${ }^{81}$ Interleukin-1 has been detected in the synovial fluid of equine osteoarthritis. ${ }^{82}$ Two facts suggest this is an important point to resolve. Glucocorticoids have been shown to prevent progression of disease in osteoarthritis models, in contrast with non-steroidal anti-inflammatory drugs, which have no effect. Glucocorticoids have many effects, including reduction of collagenase production, which may mediate this improvement. It must be remembered that another powerful activity is the reduction of cytokine expression. The second fact relates to reports that non-steroidal anti-inflammatory drugs, which reduce prostaglandin concentrations, may cause a more rapid deterioration of osteoarthritis. ${ }^{83}$ The mechanisms by which this might occur are unclear but, possibly, suppression of the prostaglandin negative feedback on IL-1 production may contribute to this deterioration

\section{Conclusion}

The increasing in vivo definition of cytokine activities and distribution promises to provide the clinician with explanations of disease pathology. Important lessons about the ease of non-physiological stimulation of cells (recently illustrated by the in vitro production of tumour necrosis factor $\alpha$ in patient samples ${ }^{84}$ ) mean that clinical studies must be meticulously planned and executed if meaningful data are to be gained. With the availability of ultrasensitive techniques using the polymerase chain reaction to detect very low concentrations of cytokine mRNA $^{85}$ the complex control of production of many cytokines must be remembered, and cytokine production should preferably be reported at both the mRNA and peptide level. The recombinant materials, specific monoclonal antibodies, and techniques are now available to ensure a continuation of the recent encouraging increase of studies to define in vivo cytokine function.

The findings for IL-1 described in this review give an indication of the potential available information but have little meaning in isolation. A more complete picture of the cytokine network that operates in many diseases will emerge when the range of cytokines is assessed at the site of disease activity. It may become apparent that there is a hierarchy of cytokines in different diseases which might be regulated by inhibiting the actions of a limited number of cytokines. At present the great overlap of cytokine activities suggests to many in this field that this will not be the case. An interesting hypothesis would suggest that so called 'non-inflammatory' diseases such as osteoarthritis, which may have a limited number of participating cytokines, may be more appropriate targets for these immunotherapies of the future.

I am grateful to Professor Gabriel Panayi, London, and Dr John Hamilton, Melbourne, for their most helpful advice about the manuscript. Dr Kirkham is supported by the Peel Medical Research Trust and Arthritis and Rheumatism Council.

1 Mizel S B, Farrar J J. Revised nomenclature of antigennonspecific $T$-cell proliferation and helper factors. Cell Immunol 1979; 48: 433-6.

2 Oppenheim J J, Kovacs E J, Matsushima K, Durum S K. There is more than one interleukin 1. Immunol Today 1986; 7: $45-56$.

3 Herrmann A F, Oster W, Meuer S C, Lindemann A, 
Mertelsmann R H. Interleukin 1 stimulates T lymphocytes to produce granulocyte-monocyte colony-stimulating factor. 7 Clin Invest 1988; 81: 1415-8.

4 Rossi V, Breviario F, Ghezzi P, Dejana E, Mantovani A. Prostaglandin synthesis induced in vascular cells by interleukin-1. Science 1985; 229: 174-6.

5 Dalton B J, Connor J R, Johnson W J. Interleukin-1 induces interleukin- $1 \alpha$ and interleukin-1 $\beta$ gene expression in synovial fibroblasts and peripheral blood monocytes. Arthritis Rhewon 1989, 32: 279-87.

6 Jirik F R, Podor T J, Hirano T, et al. Bacterial lipopolysaccharide and inflammatory mediators augment IL-6 secretion by human endothelial cells. I Immunol 1989; 142: $144-7$.

7 Giri J G, Kincade P W, Mizel S B. Interleukin-1 mediated induction of kappa-light chain synthesis and surface immunoglobulin expression on pre-B cells. $\mathcal{f}$ Immunol 1984; 132: 223-8.

8 Mantovani A, Dejana E. Cytokines as communication signals between leukocytes and endothelial cells. Immunol Today 1989; 10: 370-5.

9 Hasty K A, Reife R A, Kang A H, Stuart J M. The role of stromelysin in the cartilage destruction that accompanies
inflammatory arthritis. Arthritis Rheum 1990; 33: 388-97.

10 Leizer T, Clarris B J, Ash P E, van Damme J, Saklatvala J, Hamilton J A. Interleukin- $1 \beta$ and interleukin- $1 \alpha$ stimulate the plasminogen activator activity and prostaglandin $E_{2}$
levels of human synovial cells. Arthritis Rheum 1987; 30: 562-6.

11 Dayer J-M, de Rochemonteix B, Burrus S, Demezuks S, Dinarello $C$. Human recombinant interleukin-1 stimulates collagenase and prostaglandin $E_{2}$ production by synovial collagenase and prostaglandin $\mathrm{E}_{2}$ prod

12 Dodge $G \mathrm{R}$. Poole A R. Immunohistochemical detection and immunochemical analysis of type II collagen degradation in human normal, rheumatoid and osteoarthritic articular cartilages and in explants of bovine articular cartilage
cultured with interleukin $1 . \mathcal{G}$ Clin Invest 1989; 83: 647-61.

13 Rifas L, Shen F, Mitchell K, Peck W A. Macrophage-derived growth factor for osteoblast-like cells and chondrocytes. Proc Natl Acad Sci USA 1984; 81: 4558-62.

14 di Giovine F S, Duff G W. Interleukin 1: the first interleukin. Immunol Today 1990; 11: 13-20.

15 Dinarello C A. Biology of interleukin 1. FASEB J 1988; 2: 108-15.

16 Schindler R, Dinarello C A. A method for removing interleukin- 1 and tumor necrosis factor-inducing substances from bacterial cultures by ultrafiltration with polysulfone. f Immunol Methods 1989; 116: 159-65.

17 Knudsen P J, Dinarello C A, Strom T B. Glucocorticoids inhibit transcriptional and post-transcriptional expression of interleukin 1 in U937 cells. $f$ Immunol 1987; 139: 4129-34.

18 Kern J A, Lamb R J, Reed J C, Daniele R P, Nowell P C. Dexamethasone inhibition of interleukin 1 beta production by human monocytes. Post-transcriptional mechanisms. J Clin Invest 1988; 81: 237-44.

19 Knudsen P J, Dinarello C A, Strom T B. Prostaglandins posttranscriptionally inhibit monocyte expression of interleukin 1 activity by increasing intracellular cyclic adenosine monophosphate. I I mmunol 1986; 137: 3189-94.

20 Baldari C T, Telford J L. The intracellular precursor of IL$1 \beta$ is associated with microtubules in activated U937 cells. I Immunol 1989; 142: 785-91.

21 Libby P, Ordovas J M, Birinyi L K, Auger K R, Dinarello $C A$. Inducible interleukin-1 gene expression in human vascular smooth muscle cells. I Clin Invest 1986; 78: $1432-8$.

22 Kurt-Jones E A, Beller D I, Mizel S B, Unanue E R. Identification of a membrane-associated interleukin 1 in macrophages. Proc Natl Acad Sci USA 1985; 82: 1204-10.

Suttles , Carruth L M, Mizel S B. Detection of IL-1 $\alpha$ and human monocytes. Evidence against a membrane form of IL-1. I Immunol 1990; 144: 170-4.

24 Dinarello C A, Clark B D, Puren A J, Savage N, Rosoff P M. The interleukin 1 receptor. Immunol Today 1989; 10: 49-51.

25 Dinarello C A. Interleukin-1 and its biologically related cytokines. Adv Immunol 1989; 44: 153-205.

26 Nouri A M E, Panayi G S, Goodman S M. Cytokines and the chronic inflammation of rheumatic disease. I. The presence of interleukin-1 in synovial fluids. Clin Exp Immunol 1984 55: 295-302.

27 Lotz M, Tsoukas C D, Robinson C A, Dinarello C A, Carson D A, Vaughan J H. Basis for defective responses of rheumatoid arthritis synovial fluid lymphocytes to ant-

28 Balavoine J-F, Rochemonteix B de, Williamson $\mathrm{K}$, Seckinger $P$, Cruchard A, Dayer J-M. Prostaglandin $E_{2}$ and collagenase production by fibroblasts and synovial cells is regulated by urine-derived human interleukin 1 and regulated by urine-derived human inter

29 Hannum C H, Wilcox C J, Arend W P, et al. Interleukin-1 receptor antagonist activity of a human interleukin-1 inhibitor Nature 1990; 343: 336-40.

30 Eisenberg S P, Evans R J, Arend W P, et al. Primary structure and functional expression from complementary DNA of a human interleukin-1 receptor antagonist. Nature 1990; 343: 341-6.

31 Arend W P, Joslin F G, Thompson R C, Hannum C H. An IL-1 inhibitor from human monocytes. Production and characterisation of biologic properties. I Immunol 1989, 143: $1851-8$.
32 Arend W P, Dayer J-M. Cytokines and cytokine inhibitors or antagonists in rheumatoid arthritis. Arthritis Rheum 1990; 33: 305-15.

33 James K. Interactions between cytokines and $\alpha_{2}$-macroglobulin. Immunol Today 1990; 11: 163-6.

34 Bendtzen K, Svenson M, Jonsson V, Hippe E. Autoantibodies to cytokines-friends or foes? Immunol Today 1990; 11:

35 Sims J E, March C J, Cosman D, et al. cDNA expression cloning of the IL-1 receptor, a member of the immunoglobulin superfamily. Science 1988; 241: 585-9.

36 Chin J, Rupp E, Cameron P M, et al. Identification of a highaffinity receptor for interleukin $1 \alpha$ and interleukin $1 \beta$ on cultured human rheumatoid synovial cells. $\mathcal{F}$ Clin Invest 1988; 82: 420-6.

37 Balkwill F R, Burke F. The cytokine network. Immunol Today 1989; 10: 299-304.

38 Guerne P-A, Carson D A, Lotz M. IL-6 production by human articular chondrocytes. Modulation of its synthesis by cytokines, growth factors, and hormones in vitro. $\mathcal{F}$ Imenanol 1990, 144: 499-505.

39 Mielke V, Bauman J G J, Sticherling M, et al. Detection of neutrophil-activating peptide NAP/IL-8 and NAP/IL8 mRNA in human recombinant IL-l $\alpha$ - and human recombinant tumor necrosis factor- $\alpha$-stimulated human dermal fibroblasts. F Immunol 1990; 144: 153-61.

40 Kumkumian G K, Lafyatis R, Remmers E F, Case J P, Kim S-J, Wilder R L. Platelet-derived growth factor and IL-1 interactions in rheumatoid arthritis. Regulation of synoviocyte proliferation, prostaglandin production and collagenase cyte proliferation, prostaglandin production

41 Ucla C, Roux-Lombard P, Fey S, Dayer J-M, Mach B. Interferon gamma drastically modifies the regulation of Interferon gamma drastically modifies the regulation of
interleukin 1 genes by endotoxin in U937 cells. $\mathcal{C}$ Clin Invest 1990; 85: 185-91.

42 Hopkins S J, Humphreys M, Jayson M I V. Cytokines in synovial fluid. I. The presence of biologically active and immunoreactive IL-1. Clin Exp Immunol 1988; 72: 422-7.

43 Shiozawa S, Shiozawa K, Tanaka Y, et al. Human epidermal growth factor for the stratification of synovial lining layer and neovascularisation in rheumatoid arthritis. Ann Rheum Dis 1989; 48: 820-8.

44 Hopkins S J. Cytokines and eicosanoids in rheumatic diseases. Ann Rheum Dis 1990; 49: 207-11.

45 Endres S, Ghorbani R, Kelley V E, et al. The effect of dietary supplementation with $n-3$ polyunsaturated fatty acids on the synthesis of interleukin- 1 and tumor necrosis factor by mononuclear cells. N Engl I M Med 1989; 320: 265-71.

46 Buchan G, Barrett K, Turner M, Chantry D, Maini R N, Feldmann $M$. Interleukin-1 and tumour necrosis factor mRNA expression in rheumatoid arthritis: prolonged production of IL-1 $\alpha$. Clin Exp Immunol 1988; 73: 449-55.

47 Firestein G, Xu W-D, Townsend $K$, et al. Cytokines in chronic inflammatory arthritis. I. Failure to detect $T$ cell lymphokines (interleukin 2 and interleukin 3) and presence of macrophage stimulating factor (CSF-1) and a novel mast cell growth factor in rheumatoid synovitis. $\mathcal{7}$ Exp Med 1988; 168: 1573-86.

48 Husby G, Williams R C. Synovial localisation of tumor necrosis factor in patients with rheumatoid arthritis. $\mathcal{F}$ Autoimmun 1988; 1: 363-71.

49 Duff $G$ W. Peptide regulatory factors in non-malignant disease. Lancet 1989; i: 1432-5.

50 Koch B, Baum W, Burmester G R, et al. Prostaglandin $E_{2}$, interleukin 1 and gamma interferon production of mononuclear cells of patients with inflammatory and degenerative joint diseases. $Z$ Rheumatol 1989; 48: 194-9.

51 Goto M, Fujisawa M, Yamada A, et al. Spontaneous release of angiotensin converting enzyme and interleukin $1 \beta$ from peripheral blood monocytes from patients with rheumatoid arthritis under a serum free condition. Ann Rheum Dis 1990; 49: 172-6.

52 Kirkham B W, Navarro F J, Corkill M M, Barbatis C, Panayi G S. Immunohistochemical localization of interleukin 1 in rheumatoid and osteoarthritis synovial membrane rheumatoid and osteoarthritis synovial me

53 Kirkham B W, Navarro F J, Corkill M M, Gibson T, Panayi G S. Change in interleukin 1 beta expression in rheumatoid synovial membrane after treatment with gold and glucosynovial membrane after treatment with gold and g
corticoid [Abstract]. Clin Rherumatol 1990; 9: 118-9.

54 Henderson B, Pettipher E R. Comparison of the in vivo inflammatory intra-articular injection of natural and recombinant IL-1 alpha and IL-1 beta in the rabbit. Biochem Pharmacol 1988; 37: 4171-6.

55 Henderson B, Pettipher E R. Arthritogenic actions of recombinant IL-1 and tumour necrosis factor $\alpha$ in the rabbit: evidence for synergistic interactions between cytokines in vivo. Clin Exp Immunol 1989; 75: 306-10.

56 Stimpson S A, Dalldorf F G, Otterness I G, Schwab J H Exacerbation of arthritis by IL-1 in rat joints previously injured by peptidoglycan-polysaccharide. $\mathcal{F}$ Immunol 1988; 140: $2964-9$.

57 Staite N D, Richard K A, Aspar D G, Franz K A, Galinet L A, Dunn C J. Induction of an acute erosive monarticular arthritis in mice by interleukin-1 and methylated bovine serum albumin. Arthritis Rheum 1990; 33: 253-60.

58 Killar L M, Dunn C J. Interleukin-1 potentiates the development of collagen-induced arthritis in mice. Clin $\mathrm{Sc}$

59 Jacobs C, Young D, Tyler S, Callis G, Gillis S, Conlon P J. In vivo treatment with IL-1 reduces the severity and duration of antigen-induced arthritis in rats. F Immunol 1988; 141 2967-74.

60 Okusawa S, Gelfand J A, Ikejima T, Connolly R J, Dinarello 
C A. Interleukin 1 induces a shock-like state in rabbits. Synergism with tumor necrosis factor and the effect of cyclooxygenase inhibition. $\mathcal{F}$ Clin Invest 1988; 81: 1162-72. 61 Cominelli F, Nast C C, Lierena R, Dinarello C A, Zipser $R$ D. Interleukin 1 suppresses inflammation in rabbit colitis. Mediation by endogenous prostaglandins. $\mathcal{f}$ Clin colitis. Mediation by

62 Henderson B, Rowe F M, Bird C R, Gearing A J H Production of interleukin 1 in the joint during the development of antigen-induced arthritis in the rabbit. Clin Exp Immunol 1988; 74: 371-6.

63 Saxne T, Di Giovine F S, Heinegard D, Duff G W, Wollheim F A. Synovial fluid concentrations of interleukin-1 beta an proteoglycans are inversely related. F Autoimmun 1988; 4 : 373-80.

64 Miyasaka N, Sato K, Goto M, et al. Augmented interleukin-1 production and HLA-DR expression in the synovium of rheumatoid arthritis patients. Possible involvement in joint destruction. Arthritis Rheum 1988; 31: 480-6.

65 Seibel M J, Bruckle W, Respondek M, Beveridge T Schnyder J, Muller W. Initial clinical experiences in the treatment of chronic polyarthritis with a new monokine release inhibitor. $Z$ Rheumatol 1989 ; 48: 147-51.

66 Smith J B, Bocchieri M H, Sherbin-Allen L, Borofsky M Abruzzo J L. Occurrence of interleukin-1 in huma synovial fluid: detection by RIA, bioassay and presence of bio-assay inhibiting factors. Rheumatol Int 1989; 9: 53-8.

67 Hamerman D. The biology of osteoarthritis. N Engl f Med 1989; 320: $1322-30$.

68 Brown R A, Weiss J B. Neovascularisation and its role in the osteoarthritic process. Ann Rheum Dis 1988; 47: 881-5.

69 Arner E C, Pratta M A. Independent effects of interleukinon proteoglycan breakdown, proteoglycan synthesis, and prostaglandin $\mathrm{E}_{2}$ release from cartilage in organ culture. Arthritis Rheum 1989; 32: 288-97.

70 Campbell I K, Piccoli D S, Roberts M J, Muirden K D, Hamilton J A. Effects of tumour necrosis factor $\alpha$ and $\beta$ o resorption of human articular cartilage and production of plasminogen activator by human articular chondrocytes. Arthritis Rheum 1990; 33: 542-52.

71 di Giovine F, Nuki G, Duff G W. Tumour necrosis factor in synovial exudates. Ann Rheum Dis 1988; 47: 768-72.

72 Goldring M B, Birkhead J, Snadell L J, et al. Interleukin 1 suppresses expression of cartilage specific types II and IX collagens and increases type I and III collagens in human chondrocytes. F Clin Invest 1988; 82: 2026-37.
73 Lindblad S. Arthroscopic and synovial correlates of pain in osteoarthritis. Semin Arthritis Rheum 1989; 18 (suppl 2): 91-3.

74 Revell P A, Mayston V, Lalor P, Mapp P. The synovia membrane in osteoarthritis: a histological study including the characterisation of the cellular infiltrate present in the characterisation of the cellular infiltrate present in inflammatory osteoarthritis using

75 Pelletier J-P, Martel-Pelletier J. Evidence for the involvement of interleukin 1 in human OA cartilage degradation protective effect of NSAID. $\mathcal{I}$ Rheumatol 1989; 16 (supp 18): 19-27.

76 Shinmei M, Masuda K, Kikuchi T, Shimomura Y. Interleukin 1 , tumour necrosis factor and interleukin 6 as mediators of cartilage destruction. Semin Arthritis Rheum 1989; 18 (suppl 2): 27-32.

77 Campen D H, Horwitz D A, Quismorio F P, Ehresmann G R, Martin W J. Serum levels of interleukin-2 receptor and activity of rheumatic diseases characterized by immune and activity of rheumatic diseases characterized by imm

$78 \mathrm{Ziff} M$. Relation of cellular infiltration of rheumatoid synovia membrane to its immune response. Arthritis Rheum 1974; 17: 313-9.

79 Brennan F M, Chantry D, Jackson A, Maini R, Feldmann $M$. Inhibitory effect of TNF $\alpha$ antibodies on synovial cell interleukin-1 production in rheumatoid arthritis. Lancet 1989; ii: $244-7$.

80 Goto M, Yoshinoya S, Miyamoto T, et al. Stimulation of interleukin-1 alpha and interleukin-1 beta release from human monocytes by cyanogen bromide peptides of type II collagen. Arthritis Rheum 1988; 31: 1508-14.

81 Altman R D, Dean D D. Osteoarthritis research: animal models. Semin Arthritis Rheum 1990; 19 (suppl 1): 21-5.

82 Morris E A, McDonald B S, Webb A C, Rosenwasser L J. Identification of interleukin-1 in equine osteoarthritic joint Identification of interleukin-1 in equine osted
effusions. Am $\mathcal{F}$ Vet Res 1990; 51: 59-64.

83 Rashad S, Revell P, Hemingway A, Low F, Rainsford K, Walker $F$. Effect of non-steroidal anti-inflammatory drugs on the course of osteoarthritis. Lancet 1989; ii: 519-22.

84 Freeman R, Wheeler J, Robertson H, Paes M L, Laidler J. In vitro production of TNF- $\alpha$ in blood samples. Lancet 1990; 336: 312-3.

85 Brenner C A, Tam A W, Nelson P A, et al. Message amplification phenotyping (MAPPing): a technique to simultaneously numbers of cells. Biotechniques 1989; 7: 1096-103. 